\title{
Impact of Psychosocial Factors on the Adolescents’ Behaviour
}

\author{
Beatrice Olawumi Ajidahun \\ Faculty of Education, Department of Guidance and Counselling, Adekunle Ajasin University, \\ Akungba-Akoko, Nigeria. \\ Email: wumiajid@yahoo.co.uk \\ Received May 31 ${ }^{\text {st }}$, 2011; revised July 3 ${ }^{\text {rd }}$, 2011; accepted July $12^{\text {th }}, 2011$.
}

\begin{abstract}
The study examined poverty, divorce and peer-pressure as correlates of behavioural problems among adolescents in Adekunle Ajasin University. A total number of 100 students were randomly selected from various Departments in the Faculty of Education. The research instrument titled: Adolescent Psychological Questionnaire (APQ) consisting of 18 items was administered to the adolescents in the Faculty. Four research hypotheses were formulated. The data were analysed using frequency count and Chi-Square statistics. Results showed that all the hypotheses tested were significant. This implies that poverty, divorce and peer-pressure were correlates of behavioural problems among adolescents in the Faculty of Education, Adekunle Ajasin University, AkungbaAkoko, Nigeria.
\end{abstract}

Keywords: Psychology, Adolescents, Behaviors

\section{Introduction}

Adolescence period is very essential to the growth of any person. The peculiarities of this period make it unique from other aspects of development. It is a transitional period from childhood to adulthood; it requires an atmosphere full of love and understanding to function well. In Nigeria today, many adolescents are getting into problems simply because of how they were nurtured and what they were exposed to in the course of growing up. Growing up in Nigeria sometimes depends on the types of homes and parents one has. The economic status of the homes whether low or high may likely contribute to the positive or negative development of the adolescents. The homes too, whether loving, caring and supportive may contribute enormously to the proper development of the adolescent child.

The well being of every adolescent starts from the home. The home being the first agent of socialization needs proper nurturing for it to fulfill its obligation to the members. Adolescents benefit enormously when one or both parents are highly involved in their upbringing. The act of nurturing the young ones to adolescence stage is a great task for every parent to fulfill. Upbringing of the adolescents starts from attending to their physical needs based on the various physical developments they are experiencing. Apart from upbringing, lack of warmth and nurture from the parents may affect the development of selfcontrol in adolescents. An environment characterized by love, understanding and good health is expected to promote the well being of adolescents.

According to Conger and Chao (1996), adolescents in divorced families are more likely than adolescents from intact homes to have less intimate relationship with their parents. Sometimes they also drop out of school because of lack of concentration; they could become sexually active at an earlier age because there may not be proper monitoring of their behaviour. Apart from this, they sometimes take to drugs and associate with anti-social peers and this may lead to having lower self-esteem.

According to Furstenberg et al. (2001), the family needs to be intact for adolescents to experience the warmth and nurture of a loving family. Emotional and behavioural problems may stem from parental conflict before and after divorce, as well as from the separation itself. In the view of Young et al. (1997), a smooth functioning family can provide support and nurture to an adolescent during times of stress and crises. Adolescents from divorced, single-parent family tend to do worse in school and get into trouble with the school authorities more than do adolescents from two parents homes, perhaps because single parents find it difficult to monitor their children on top of their other responsibilities .

Adolescence period is sometimes referred to as a period of stress and storm due to some biological changes they do experience in their bodies. If the stressors are increased by parents' marital breakdown then adolescents concerned may be stressed the more. As noted by Pelton and Forehand (2001), the family then becomes a source of stress as a result of divorce. Both parents have roles to play in the lives of adolescents and these roles cannot be overemphasized. Cooney and Mortimer (1999) observed that divorce may be a kind of distraction that disrupts the functions of parents to their children. The absence of father in homes may lead to aggressive behaviour and poor adjustment. During the teenage years, the father often assumes the primary responsibility for disciplining the male adolescents who sometimes exhibit more antisocial and delinquent behavior.

According to Mcloyd (2000), the financial strength of a home is worsened by divorce since both parents are no longer together. The financial stand of the home is left in the care of the mother whose financial strength may not be able to support the children. Such mothers are more distressed than their counterparts in intact homes. They often show lower support, nurture and involvement with their children. Divorce generally has effects on both sexes of adolescents but in different ways. Kelly (2000) affirmed that there are lots of negative effects of divorce on males than females.

Wolfinger (1998) found that adolescent males are prone to drinking problems due to parental divorce. On the other hand, girls from single parents are more likely to leave home after school. Both girls and boys from divorced families tend to be more depressed, according to Simons (1999) than their same aged peers from intact families. 
Akinbola (2004) observed that parents who are together may suffer poverty. It is a state where an individual is not able to cater adequately for his or her basic needs of food, clothing and shelter. He is unable to meet social and economic obligations. Lack of gainful employment, skills, assets and self-esteem has limited chances advancing his or her welfare to the limit of his capacities. Due to this high rate of poverty in the country, most parents find it difficult to provide adequate food, clothing, shelter or even good education for their children. Akinbola (2004) further affirmed that adolescents who are deprived of basic life necessities by poverty exhibit aggression and poor social dispositions. They are predisposed to violence due to lack of basic provisions of good nutrition, shelter and health care.

This aggression has manifested in the high rate of armed robbery cases committed by adolescents. In addition to this cultism, rape, sexual abuses and drug abuses are common among adolescents from poor homes. Poverty can harm children's development through its impact on parents' emotional state and parenting practices and on the home environment they create. Poor housing for parents make them worry and those who have lost their job worried about their next meal and this makes them to feel a lack of control over their lives and eventually they may likely become anxious, depressed or irritable. And they are likely to project these negative emotions on their children.

Parents may become less affectionate with and less responsive to their adolescent children. The children in turn tend to become depressed themselves. According to Evans and English (2002) adolescent's children have trouble along with peers and also lack self-confidence. As noted by the researcher, poverty, family stress, and adolescents' social and emotional problems exist among rural, low-income Nigerians. Families under economic stress are less likely to monitor their children's activities and lack of monitoring is associated with poorer school performance and social adjustment. Poverty has the tendency of sapping parents' confidence in their ability to affect their adolescent children's development. Evans et al. (2002) observed that lack of financial resources can also make it harder for mothers and fathers to support each other in parenting. Many poor parents neglect their adolescent's children by not being involved in their activities. They never knew the whereabouts of their children. And, these attitudes may make the adolescents to be socially incompetent and also expose them to biological risk factor such as AIDS.

According to Bolland (2003) a nation is deprived of competency and productiveness as it ought to have if her adolescents reach adulthood unhealthy, unskilled, or alienated. Poverty is an economic hardship and it has effects on adolescents from poor homes. This hardship may be in terms of poor health, inadequate house, homelessness, exposure to diseases and unsupportive neighbourhood. All these hardships experienced by adolescents from poor homes have implications on their behaviours. Such adolescents are invariably involved in robbery, kidnapping, prostitutions, and cultism and so on. The psychological ramification of living in poverty makes one to look down on himself; they are vulnerable to any behavioural psychological problems.

Peer pressure is another variable that affects the behaviour of the adolescents. Peer pressure can be both negative and positive. The researcher observed that the negative aspect of peer pressure strives more than the positive aspect. Adolescents belong to one peer group or the other as a source of identity and social support. They conform to the ideas, beliefs and judgment of the peer group and they spend much more time, with their peers than parents. According to Conger and Chao (1996), adolescents spend more time with peers because of low self-esteem, and internal pressure which makes adolescents susceptible to peer pressure. The authors believe that adolescents who see themselves as unintelligent, unpopular and unattractive are more vulnerable to peer pressure because their hunger for a sense of acceptance and approval compel them to seek such things through conformity. Roediger (1996) is of the opinion that the influence of peer group on behavioural development of adolescents can be examined by how they spend their free-time.

Adolescents spend much time with peers and receive less adult supervision and control. They try to avoid close supervision by parents. They become more aware of the values and behaviour of their peer group. And this lures them to some behavioural problems which are anti-social in nature such as robbery, cultism, prostitution and drug abuse. In order to feel belonged and be part of their groups, adolescents sometimes conform most of the time because of the benefit they derive in joining their friends. Some of the benefits may be financial benefits, hailing and acceptance.

\section{Research Instrument}

The data for the study were generated through "Adolescent Behavioural Questionnaire” prepared by the researcher. The questionnaire contains 18 items and is divided into section A and B. Section B consists of 18 items which are intended to find out the cause of behavioural problems among adolescents. The response format is agree and disagree.

\section{Data Analysis}

Chi-Square was used to test the hypotheses. All the hypotheses were tested at 0.05 level of significance.

Population: The population for this study is all students in the Faculty of Education, Adekunle Ajasin University, AkungbaAkoko, Nigeria. One hundred (100) students were randomly sampled from all the departments and levels.

Hypothesis One: Poverty is not significantly related to behavioural problems of adolescents.

The result is significant because the Chi-square calculated is greater than the table value of 3.841 .

Hypothesis Two: Single parenting is not significantly related to behavioural problems of adolescents.

The result is significant because chi-square calculated is greater than the table value. The hypothesis is, therefore, not accepted.

Hypothesis Three: Broken home is not significantly related to behavioural problems among adolescents.

The result is significant. Therefore, the hypothesis is not accepted.

Hypothesis Four: Peer Pressure is not significantly related to behavioural problems among adolescents.

The result is significant. Therefore, the hypothesis is not accepted.

\section{Discussion}

The result in Table 1 shows that there is significant relationship between poverty and adolescents' behavioural problems. Factors like inadequate feeding, lack of shelter, hunger and 
poor education encourage adolescents to misbehave. This finding agrees with Akinbola (2004) that adolescents deprived of basic necessities of life by poverty exhibit aggression and poor social dispositions. The result in Table 2 indicates that there is significant relationship between single parenting and adolescents' behavioural problems. Factors like the absence of a father or mother at home, financial handicapping of the father or mother and transfer of aggression influence children of single parents to misbehave. This agrees with Furstenberg et al. (2001) that family needs to be intact for adolescents to experience the warmth and nurture of a loving family.

Table 3 result shows that there is a significant relationship between broken home and adolescents' behavioural problems.

Table 1.

Responses of adolescents on poverty as a factor for behavioural problems.

\begin{tabular}{|c|c|c|c|c|}
\hline No & \multicolumn{2}{|r|}{ Items } & Agree & Disagree \\
\hline 1. & \multicolumn{2}{|c|}{$\begin{array}{l}\text { Some adolescents are engaging } \\
\text { in robbery because of their poor } \\
\text { background. }\end{array}$} & 75 & 25 \\
\hline 2. & \multicolumn{2}{|c|}{$\begin{array}{l}\text { Nigerian adolescents who lack } \\
\text { basic needs like food are prone } \\
\text { to robbery. }\end{array}$} & 64 & 36 \\
\hline 3. & \multicolumn{2}{|c|}{$\begin{array}{l}\text { Adolescents from large families } \\
\text { lack basic needs of life like shelter } \\
\text { and clothing }\end{array}$} & 42 & 58 \\
\hline 4. & \multicolumn{2}{|c|}{$\begin{array}{l}\text { Poverty hinders parents from moni- } \\
\text { toring their children's whereabouts. }\end{array}$} & 50 & 50 \\
\hline 5. & \multicolumn{2}{|c|}{$\begin{array}{l}\text { Parents who provide for the basic } \\
\text { needs of their children command } \\
\text { respect. }\end{array}$} & 80 & 20 \\
\hline \multirow[t]{2}{*}{6.} & \multicolumn{2}{|c|}{$\begin{array}{l}\text { Many adolescents are hindered } \\
\text { in their pursuit of education be- } \\
\text { cause of poverty. }\end{array}$} & 83 & 17 \\
\hline & \multicolumn{2}{|r|}{ Total } & 394 & 206 \\
\hline \multicolumn{2}{|c|}{ Responses } & \multicolumn{2}{|c|}{ Average Observed Responses } & $\mathrm{X}^{2} \mathrm{c}$ \\
\hline \multicolumn{2}{|c|}{ Agree } & $65.66(50)^{*}$ & \multicolumn{2}{|r|}{9.81} \\
\hline \multicolumn{2}{|c|}{ Disagree } & $34.33(50)^{*}$ & & \\
\hline
\end{tabular}

$\mathrm{X}^{2} \mathrm{t}=3.841 \mathrm{P}<0.05$ (Significant result); * Expected cell frequency.

Table 2.

Responses of adolescents on staying together of parents.

\begin{tabular}{|c|c|c|c|c|}
\hline No & & Items & Agree & Disagree \\
\hline 1. & \multicolumn{2}{|c|}{$\begin{array}{l}\text { Single parenting affects the lives of } \\
\text { adolescents negatively. }\end{array}$} & 85 & 15 \\
\hline 2. & \multicolumn{2}{|c|}{$\begin{array}{l}\text { Boys/girls who are trained by single } \\
\text { parents especially mothers are prone to } \\
\text { anti-social behaviours. }\end{array}$} & 75 & 25 \\
\hline & \multicolumn{2}{|r|}{ Total } & 150 & 40 \\
\hline \multicolumn{2}{|c|}{ Responses } & Average Observed Responses & df & $\mathrm{X}^{2} \mathrm{c}$ \\
\hline \multicolumn{2}{|c|}{ Agree } & $75(50)^{*}$ & & 24.5 \\
\hline \multicolumn{2}{|c|}{ Disagree } & $20(50)^{*}$ & & \\
\hline
\end{tabular}

$\mathrm{X}^{2} \mathrm{t}=3.841 \mathrm{P}<0.05$ (Significant result); *Expected cell frequency.
This agrees with Pelton and Forehand (2001) that the family becomes a source of stress as a result of divorce.

The result in Table 4 shows that there is a significant relationship between peer pressure and adolescents' behavioural problems. This agrees with Conger and Chao (1996) that adolescents append more time with peers because of low self-esteem and internal pressure, which makes adolescents susceptible to peer pressure.

Table 3.

Responses of adolescents on broken homes.

\begin{tabular}{|c|c|c|c|c|}
\hline No & & Items & Agree & Disagree \\
\hline 1. & \multicolumn{2}{|c|}{$\begin{array}{l}\text { Adolescents from broken homes } \\
\text { are liable to anti social behaviour. }\end{array}$} & 81 & 19 \\
\hline 2. & \multicolumn{2}{|c|}{$\begin{array}{l}\text { Low-self concepts of adolescents } \\
\text { from broken and poor homes are } \\
\text { responsible for depression. }\end{array}$} & 74 & 36 \\
\hline 3. & \multicolumn{2}{|c|}{$\begin{array}{l}\text { Most girls from broken homes are } \\
\text { lured into early marriage in life }\end{array}$} & 87 & 13 \\
\hline 4. & \multicolumn{2}{|c|}{$\begin{array}{l}\text { Adolescents from broken homes } \\
\text { always feel bad about themselves. }\end{array}$} & 76 & 24 \\
\hline \multirow[t]{2}{*}{5.} & \multicolumn{2}{|c|}{$\begin{array}{l}\text { Adolescents from both broken homes } \\
\text { and poor background experience } \\
\text { more stress than those from either } \\
\text { intact or poor homes. }\end{array}$} & 86 & 14 \\
\hline & \multicolumn{2}{|r|}{ Total } & 404 & 106 \\
\hline \multicolumn{2}{|c|}{ Responses } & Average Observed Responses & df & $\mathrm{X}^{2} \mathrm{C}$ \\
\hline \multicolumn{2}{|c|}{ Agree } & $80.8(50)^{*}$ & \multirow{2}{*}{1} & 35.56 \\
\hline Dis & & $21.2(50)^{*}$ & & \\
\hline
\end{tabular}

Table 4 .

Responses of adolescents on peer pressure.

\begin{tabular}{|c|c|c|c|}
\hline No & Items & Agree & Disagree \\
\hline 1. & $\begin{array}{l}\text { Many adolescents belong to one } \\
\text { peer group or the other because of } \\
\text { low self esteem. }\end{array}$ & 93 & 07 \\
\hline 2. & $\begin{array}{l}\text { The thirst for acceptance among peers } \\
\text { prompts some adolescents to join } \\
\text { bad gangs. }\end{array}$ & 92 & 08 \\
\hline 3. & $\begin{array}{l}\text { To avoid parental supervision, many } \\
\text { adolescents spend more time with } \\
\text { peer groups. }\end{array}$ & 96 & 04 \\
\hline 4. & $\begin{array}{l}\text { The desire for intimate relationship } \\
\text { compels adolescents to socialize. }\end{array}$ & 90 & 10 \\
\hline \multirow[t]{2}{*}{5.} & $\begin{array}{l}\text { The desire for popularity makes ado- } \\
\text { lescents to socialize. }\end{array}$ & 91 & 09 \\
\hline & Total & 262 & 29 \\
\hline \multicolumn{2}{|r|}{ Average Observed Responses } & $\mathrm{df}$ & $\mathrm{X}^{2} \mathrm{c}$ \\
\hline Agree & $92.4(50)^{*}$ & \multirow{2}{*}{1} & 75.03 \\
\hline Disa & $5.8(50)^{*}$ & & \\
\hline
\end{tabular}

$\mathrm{X}^{2} \mathrm{t}=3.841 \mathrm{P}<0.05$ (Significant result); *Expected cell frequency. 


\section{Recommendation}

The findings of this study show that poverty, divorce, single parenting and peer pressure are all responsible for various behavioural problems of adolescents. It is therefore important to recommend the following:

- Parents should give birth to children they can adequately cater for.

- The communication line between parents and adolescent children should be kept open and effective.

- Parents should encourage their children to believe in themselves and have high self-confidence.

- Parents should show interest in the activities that their children are interested in.

\section{References}

Akinbola, R. B. (2004). Adolescents, poverty and the constitution: Contemporary issues and researches on adolescents. Ibadan: Royal People.

Bolland, J. M. (2003). Hopelessness and risk behaviour among adolescents living in high poverty inner-city neigbourhood. Journal of Adolescence, 26, 145-158.

Conger, R. D., \& Chao, W. (1996). Adolescent depressed mood. In J. W. Santrock (Ed.), Adolescence. New York: McGraw Hill.
Cooney, T., \& Mortimer, J. C. (1999). Family structure differences the timing of living home. exploring medicating factors. Journal of Research Adolescence, 9, 367-393. doi:10.1207/s15327795jra0904_1

Evans, G. W., \& English, K. (2002). The environment of poverty: Multiple stressor exposure, psycho physiological stress and socio-emotional adjustment. Child Development, 73, 1238-1248. doi:10.1111/1467-8624.00469

Furstenberg, F. F., \& Kiernan, K. E. (2001). Delayed parental divorce. How much do children benefit? Journal of Marriage and Family, 63, 446-457. doi:10.1111/j.1741-3737.2001.00446.x

Kelly, J. (2000). Children's adjustment in conflicted marriage and divorce: A decade review of research. Journal of the American Academy of Child \& Adolescent Psychiatry, 39, 963-973. doi:10.1097/00004583-200008000-00007

Mcloyd, V. C. (2000). Poverty In A. Kazdin (Ed.), Encyclopedia of Psychology. Washington DC and New York: American Psychological Association and Oxford University Press.

Roediger, H. L., Capaldi, E. D., Paris, S. G., \& Herman, C. P. (1996). Psychology. New York: West Publishing Company.

Simons, R. L., Gordon, L. C., Conger, R. D., \& Loren, X. F. O. (1999). Explaining the higher incidence of problems among children of divorce compared with those in two-parents families. Journal of Marriage and the Family, 61, 1020-1033. doi:10.2307/354021

Wolfinger, N. (1998). The effect of parental divorce on adult tobacco and alcohol consumption. Journal of Health and Social Behaviour, 39, 254-269. doi:10.2307/2676316

Young, R. A, Paseluikho, M. A., \& Valach, L. (1997). The role of emotions in the construction of career in parent-adolescent conversations. Journal of Counselling and Development, 76, 36-44. 